Original Research Article

\title{
Verbal Humor in Modern Family from the Perspective of Cooperative Principle
}

\author{
Lin Jing \\ School of Foreign Languages and Cultures, Nanjing Normal University, Jiangsu 210024, China
}

\begin{abstract}
Humor is everywhere in our daily life. From the perspective of Cooperative Principle, this research selects dialogues from the sitcom Modern Family as the corpus. Through the study of the dialogues violating the four maxims under the Cooperative Principle, this research analyzes how the sitcom achieves the comedy effect by violating the Cooperative Principle with the hope of providing certain reference for the creation of humor in the sitcom.
\end{abstract}

Keywords: Cooperative Principle; Verbal Humor; Modern Family

\section{Introduction}

Humor has been an enduring research topic. Grice's Cooperative Principle (shortened as CP) is essential in analyzing verbal humor. From the perspective of CP, this research selects lines in Modern Family as the corpus, and studies the lines violating the four maxims under $\mathrm{CP}$, and analyzes how the sitcom achieves the humorous effect by violating $\mathrm{CP}$, with the hope of providing certain reference for English learners to understand American humor.

\section{Cooperative Principle}

Grice put forward CP. He thinks that "People always provide the needed utterance or information according to the aim or direction of the conversation in verbal communication" (Grice,1975: 307).

The CP includes the following contents:

\subsection{The quantity maxim}

(1) Make your contribution as informative as is required for the current purposes of the exchange.

(2) Do not make your contribution more informative than is required.

\subsection{The quality maxim}

Try to make your contribution one that is true.

(1) Do not say what you believe to be false.

(2) Do not say that for which you lack adequate evidence.

\subsection{The relation maxim}

Be relevant.

\subsection{The manner maxim}

Be perspicuous.

(1) Avoid obscurity of expression.

(2) Avoid ambiguity.

(3) Be brief.

(4) Be orderly.

\section{The violation of $\mathbf{C P}$}

Grice (1975) deems that in the process of dialogue, not everyone will always abide by the CP. In daily communication, people violate $\mathrm{CP}$ to achieve specific purpose. By violating $\mathrm{CP}$, language effects can be produced.

For example:

This is an open-access article distributed under the terms of the Creative Commons Attribution Non-Commercial License 
A: What do you think of Lily?

B: The weather today is not so good.

In the conversation, A's intention is to ask B what B thinks of Lily, but B's answer is irrelevant. Obviously, B violates the Relation Maxim in CP.B's intention to violate CP may be that the B does not want to talk about the topic.

\section{Sitcom}

Sitcom originated in America in 1920s.Sitcom is a TV program that presents the same characters in different funny scenes. Nowadays,sitcom is closely linked with TV plays. These sitcoms promote the study of humor. The sitcom Modern Family is one of the representative works of American sitcom and a representative corpus for the study of verbal humor.

\section{Cooperative principle and verbal humor}

\subsection{Humor}

Humor is an art of social communication. However,there is no accurate definition of humor. Attardo (1994) believes that humor comes from the Latin word "liquid", which refers to a person's mood or mental state in the following years.

Scholars have different classifications of humor. Bergson (1917)believes that humor includes situational humor and verbal humor. Situational humor and verbal humor are different, but they are not mutually exclusive. The production and presentation of verbal humor can't be separated from situational context, and they are complementary (Zhang Min,2004). Other scholars have studied humor from Pragmatics (Fang Chuanyu,2010). This research studies humor from the perspective of linguistics, the author adopts Bergson's humor classification to analyze the verbal humor in Modern Family.

\subsection{Studies of verbal humor from the perspective of CP}

With the development of pragmatics, language researchers have begun to analyze verbal humor from the perspective of CP. Attardo (1994) explains the communicative nature and contradiction of jokes. Carrell (1998) holds that any speech is not humorous from the perspective of the listener. In addition, some scholars have studied the relationship between the premise and the production of humor, such as Li Lanping (2002). This research selects Modern Family as the corpus to analyze how it achieves the comedy effect by violating CP.

\section{Case Analysis}

\subsection{The violation of the quantity maxim}

In Episode 8 of Season 11, when Mitchell and Cameron's friends wanted to find a volunteer sperm donor, they asked Mitchell and Cameron for help. But Mitchell and Cameron were disappointed that they couldn't be considered.

Mitchell: It's painful. It's like not getting picked to play kickball.

Cameron: Well, that never happened to me. I was my kickball team's captain. Well, only after our star broke his leg and had to be put down. He was a...

Mitchell: A mule.

The Quantity Maxim requires that what is said in conversation should not exceed the amount of information spoken in communication. In the dialogue, when Mitchell described his disappointment, Cameron said that he was the captain to compare with Mitchell. Finally, it turned out that the "star" was a mule. In order to cover up his guilty feelings, Cameron said too much, which enabled Mitchell to expose him. By violating the Quantity Maxim, the humorous effect was generated, and highlighted Cameron's competitive character.

\subsection{The violation of the quality maxim}

In the first episode of Season 11, Manny wanted to be the director of Jay's kennel advertisement, while the voice actor was his ex-girlfriend Sherry. Manny wanted to take this opportunity to get Sherry back, but he lied to Jay.

Manny: I need to prove myself that I'm over her, that I can rise above it and be professional.

Jay: Fine, but if your emotions get in the way of this production, you will never work in dog-bed commercials again.

Manny: Don't worry. My only passion is helping you realize your creative vision.

Manny: (monologue)By day's end, Sherry will be mine.

The Quality Maxim requires that people should try to make their contribution one that is true. In the actual communication, to cover up real intention, people will deliberately say false words in specific situations, and create humorous effects. In this dialogue, Manny violated the Quality Maxim. He wanted to get Sherry back, but he lied. The lie he told Jay promoted the development of the subsequent plot, and the promise he made was in sharp contrast to the frank admission in the monologue, which enhanced the humorous effect.

\subsection{The violation of the relation maxim}

In the third episode of Season 11, Jay and Gloria met Sonia and her fiance, and they talked about Sonia's booming business. Jay learned that Gloria lost money on her business.

Gloria: It's amazing how well you've been doing selling Aunt Miranda's hot sauce. I don't want to tell you how much money I have lost trying to sell it over here.

Jay: I wouldn't mind having an exact figure.

Gloria: I can't believe that you guys are already engaged!

In this conversation, Gloria violated the Relation Maxim. The Relation Maxim requires that the content of the conversation should be relevant. In daily life, in order to avoid the embarrassment caused by direct refusal, people often shift the topic. When 
Jay learned that Gloria had lost much money, and he wanted to know the exact number, Gloria began to talk about Sonia and her fiance, which had nothing to do with the conversation. Obviously, Gloria was shifting the topic. She didn't want Jay to know about it. By violating the Relation Maxim, the writer created humorous effect and enhanced Gloria's character.

\subsection{The violation of the manner maxim}

In the third episode of Season 11, Gloria thought Sonia's fiance Nestor is a mammonist, so she drove him away. In fact, Sonia was not a rich woman. She wanted to be rich through marriage. Sonia mistook Jay's gardener for a rich man.

Sonia: Who's this?

Jay: He's the best hedge guy in town. Congratulate him. He just got a new plane.

Sonia: Oh, a hedge guy. Fascinating. How did you get started in that business?

Gardener: I bought the clippers.

The Manner Maxim requires avoiding ambiguity. The word "hedge" in English means fence or hedge fund. Jay meant that he's the best gardener in town. The plane he referred to was a model plane. However, Sonia thought that the gardener was a rich man with real plane. The word "clipper" is ambiguous. It can mean both "pliers" and "Los Angeles Clippers". Sonia mistook the gardener for a rich man. By violating the Manner Maxim, humor was created. How Sonia reacted when she thought the gardener was rich exposed her money-oriented quality. It also had the effect of humor and irony.

\section{Conclusion}

From the perspective of CP, this research analyzes the verbal humor in Modern Family caused by the violation of the four maxims of CP. It is found that in sitcoms, violation of CP can produce humorous effect and promote the characterization and the development of the plot. This research helps to provide certain reference for the creation of humor in sitcoms. Meanwhile, it is helpful for English learners to understand American humor.

There are limitations in this research. First, the corpus of the analysis is relatively insufficient; second, this research doesn't analyze with other theories. Researchers can consider these limitations when studying related issues.

\section{Reference}

1. Attrado, S. (1994). Linguistic Theories of Humor. Berlin, New York: Mouton deGruyter.

2. Bergson, H. (1917). Laughter: An Essay on the Meaning of the Comic. Macmillan, New York.

3. Fang Chuanyu (2010). A Study of Verbal Humor as a Pragmatic Strategy. Anhui University Press.

4. Grice, H.P. (1975). Logic and Conversation. New York: Academic Press.

5. Li Lanping (2002). Pragmatic Principle and English Humor. Journal of Tianjin Foreign Studies University, no.2, pp.33-37.

6. Ruch,W.\&Carrell,A. (1998). Trait Cheerfulness and the Sense of Humour. Personality \& Individual Differences, vol.24, no.4, pp.551-558.

7. Zhang Min (2004). A Pragmatic Study on Verbal Humor. Jilin University. 